\title{
$\mathbb{1}$ Pohjoismainen yhteistyö
}

\section{Helsingin sopimus}

Yhteistyösopimus Islannin,

Norjan, Ruotsin, Suomen ja

Tanskan välillä 


\section{Helsingin sopimus \\ Yhteistyösopimus Islannin, Norjan, Ruotsin, Suomen ja Tanskan välillä}

ANP 2018:718

ISBN 978-92-893-5749-4 (PDF)

http://dx.doi.org/10.6027/ANP2018-718

Helsingin sopimuksen ruotsinkieliseen versioon (2018:717)

on koottu sopimuksen kaikki kieliversiot.

(c) Pohjoismaiden ministerineuvosto ja Pohjoismaiden neuvosto 2018

\section{Pohjoismainen yhteistyö}

Pohjoismainen yhteistyö on yksi maailman laajimmista alveellisista yhteistyömuodoista.

Yhteistyön piiriin kuuluvat Islanti, Norja, Ruotsi, Suomi ja Tanska sekä Ahvenanmaa, Färsaaret ja Grönlanti.

Pohjoismaista yhteistyötä tehdään politiikan, talouden ja kulttuurin aloilla tärkeänä osana eurooppalaista ja kansainvälistä yhteistyötä. Pohjoismaisen yhteisön tavoitteena on vahva Pohjola vahvassa Euroopassa.

Pohjoismainen yhteistyö pyrkii vahvistamaan pohjoismaisia ja alveellisia etuja ja arvoja globaalissa maailmassa. Maiden yhteiset arvot lujittavat osaltaan Pohjolan asemaa yhtenä maailman innovatiivisimmista ja kilpailukykyisimmistä alveista.

\section{Pohjoismaiden ministerineuvosto}

Nordens Hus

Ved Stranden 18

1061 København K

www.norden.org

Pohjoismaisia julkaisuja voi ladata ja tilata osoitteesta www.norden.org/nordpub 


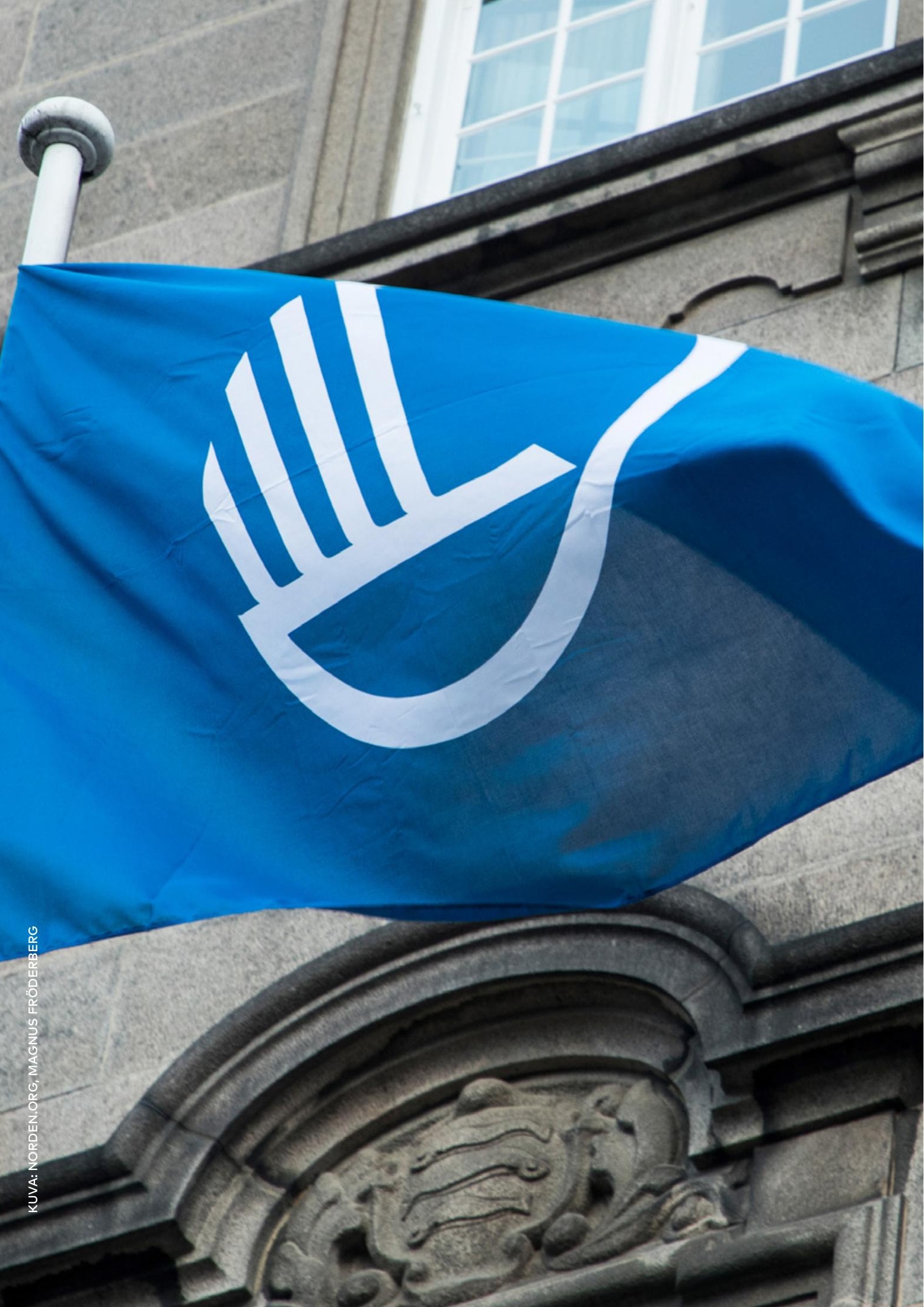




\section{Helsingin sopimus}

Yhteistyösopimus Islannin, Norjan, Ruotsin, Suomen ja Tanskan välillä

(Helsingin sopimus).

Sopimus allekirjoitettiin maaliskuun 23. päivänä 1962 ja tuli voimaan 1. päivänä heinäkuuta samana vuonna. Alkuperäistä tekstiö on muutettu sopimuksilla, jotka on allekirjoitettu helmikuun 13. päivänä 1971, maaliskuun 11. päivänä 1974, kesäkuun 15. päivänä 1983, toukokuun 6. päivänä 1985, elokuun 21. päivänä 1991, maaliskuun 18. päivänä 1993 ja syyskuun 29. päivänä 1995. Viimeisimmät muutokset astuivat voimaan tammikuun 2. päivänä 1996.

Maaliskuun 23. päivänä 1962 allekirjoitetun sopimuksen johtolause Islannin, Norjan, Ruotsin, Suomen ja Tanskan hallitukset,

jotka haluavat edelleen edistää Pohjoismaiden kansojen kesken kulttuurin sekä oikeus- ja yhteiskuntakäsitysten alalla vallitsevaa läheistä yhteisyyttä ja edelleen kehittää Pohjoismaiden välistä yhteistyötä;

jotka pyrkivät aikaansaamaan yhtenäisiä säännöksiä Pohjoismaissa mahdollisimman monilla aloilla;

jotka tahtovat kaikilla aloilla, missä siihen on edellytyksiä, aikaansaada tarkoituksenmukaisen työnjaon näiden maiden välillä;

jotka haluavat jatkaa näille maille tärkeätä yhteistyötä Pohjoismaiden neuvostossa ja muissa yhteistyöelimissä;

ovat sopineet seuraavista määräyksistä.
Helmikuun 13. päivänä 1971 allekirjoitetun sopimuksen johtolause Islannin, Norjan, Ruotsin, Suomen ja Tanskan hallitukset,

jotka haluavat lujittaa ja edelleen kehittää Pohjoismaiden välisen yhteistyön institutionaalisia perusteita,

joiden mielestä on tarkoituksenmukaista tämän tavoitteen saavuttamiseksi muuttaa Pohjoismaiden välillä 23 päivänä maaliskuuta 1962 tehtyä yhteistyösopimusta,

jotka tämän vuoksi ovat päättäneet sisällyttää yhteistyösopimukseen Pohjoismaiden neuvostoa koskevat perussäännökset,

jotka samalla ovat päättäneet sisällyttää yhteistyösopimukseen koko pohjoismaisen yhteistyön alveella toimivaltaista Pohjoismaiden ministerineuvostoa koskevat säännökset, ovat sopineet seuraavaa.

\section{Maaliskuun 11. päivänä 1974} allekirjoitetun sopimuksen johtolause Islannin, Norjan, Ruotsin, Suomen ja Tanskan hallitukset,

jotka ovat muuttaneet Pohjoismaiden välillä 23 päivänä maaliskuuta 1962 tehtyä yhteistyösopimusta sopimuksella 13 päivänä helmikuuta 1971,

joiden mielestä on tarkoituksenmukaista tehdä eräitä muita muutoksia ja lisäyksiä sopimukseen, ovat sopineet seuraavaa:

\section{Kesäkuun 15. päivänä 1983} allekirjoitetun sopimuksen johtolause Islannin, Norjan, Ruotsin, Suomen ja Tanskan hallitukset,

jotka ovat 13 päivänä helmikuuta 1971 ja 11 päivänä maaliskuuta 1974 tehdyillä sopi- 
muksilla muuttaneet Pohjoismaiden välillä 23 päivänä maaliskuuta 1962 tehtyä yhteistyösopimusta,

jotka pitävät tarkoituksenmukaisena tehdä sopimukseen tiettyjä muutoksia antaakseen Färsaarille ja Ahvenanmaalle laajemman edustuksen Pohjoismaiden neuvostossa ja Pohjoismaiden ministerineuvostossa sekä antaakseen Grönlannille vastaavan edustuksen näissä elimissä,

ovat sopineet seuraavasta:

\section{Toukokuun 6. päivänä 1985}

\section{allekirjoitetun sopimuksen johtolause}

Islannin, Norjan, Ruotsin, Suomen ja Tanskan

hallitukset,

jotka ovat 13 päivänä helmikuuta 1971, 11 päivänä maaliskuuta 1974 ja 15 päivänä kesäkuuta 1983 tehdyillä sopimuksilla muuttaneet Pohjoismaiden välillä 23 päivänä maaliskuuta 1962 tehtyä yhteistyösopimusta ja jotka haluavat tehostaa pohjoismaisen yhteistyön työmuotoja, ovat sopineet seuraavasta:

\section{Elokuun 21. päivänä 1991 allekirjoitetun sopimuksen johtolause}

Tanskan, Suomen, Islannin, Norjan ja Ruotsin hallitukset,

jotka ovat 13 päivänä helmikuuta 1971 , 11 päivänä maaliskuuta 1974, 15 päivänä kesäkuuta 1983 ja 6 päivänä toukokuuta 1985 tehdyillä sopimuksilla muuttaneet Pohjoismaiden välillä 23 päivänä maaliskuuta 1962 tehtyä yhteistyösopimusta, ja jotka pitävät tarkoituksenmukaisena tehdä tiettyjä muutoksia Pohjoismaiden neuvoston organisaatioon ja työmuotoihin, ovat sopineet seuraavasta:

\section{Maaliskuun 18. päivänä 1993} allekirjoitetun sopimuksen johtolause Tanskan, Suomen, Islannin, Norjan ja Ruotsin hallitukset, jotka ovat 13 päivänä helmikuuta 1971,
11 päivänä maaliskuuta 1974, 15 päivänä kesäkuuta 1983, 6 päivänä toukokuuta 1985 ja 21 päivänä elokuuta 1991 tehdyillä sopimuksilla muuttaneet Pohjoismaiden välillä 23 päivänä maaliskuuta 1962 tehtyä yhteistyösopimusta, ja

jotka haluavat uudistaa ja kehittää pohjoismaista yhteistyötä Pohjoismaiden Euroopan yhteistyöhön osallistumisen laajenemisen valossa,

ovat sopineet seuraavasta:

\section{Syyskuun 29. päivänä 1995}

allekirjoitetun sopimuksen johtolause

Tanskan, Suomen, Islannin, Norjan ja Ruotsin hallitukset,

jotka ovat 13 päivänä helmikuuta 1971, 11 päivänä maaliskuuta 1974, 15 päivänä kesäkuuta 1983, 6 päivänä toukokuuta 1985, 21 päivänä elokuuta 1991 ja 18 päivänä maaliskuuta 1993 tehdyillä sopimuksilla muuttaneet Pohjoismaiden välillä 23 päivänä maaliskuuta 1962 tehtyä yhteistyösopimusta, ja

jotka haluavat edelleen uudistaa ja kehittää pohjoismaista yhteistyötä Pohjoismaiden Euroopan yhteistyöhön osallistumisen laajenemisen valossa,

ovat sopineet seuraavasta:

\section{Johdantosäännös}

\section{1 artikla $(1,8)$}

Sopimuspuolten on pyrittävä säilyttämään ja edelleen kehittämään maiden välistä yhteistyötä oikeudellisella, sivistyksellisellä, sosiaalisella ja taloudellisella alalla, sekä liikenne- ja ympäristönsuojelukysymyksissä.

Sopimuspuolten on neuvoteltava keskenään niistä yhteisesti kiinnostavista kysymyksistä, joita käsitellään eurooppalaisissa ja muissa kansainvälisissä järjestöissä ja konferensseissa. 


\section{Oikeudellinen yhteistyö}

\section{2 artikla (9)}

Lakeja ja muita määräyksiä laadittaessa

Pohjoismaissa on muiden Pohjoismaiden kansalaisia kohdeltava yhdenvertaisesti oman maan kansalaisten kanssa. Tämä koskee yhteissopimuksen soveltamisaluetta.

Ensimmäisen kappaleen määräyksistä voidaan kuitenkin poiketa, jos kansalaisuusvaatimus johtuu perustuslaista, on tarpeen muiden kansainvälisten velvoitteiden johdosta tai jos tämä muista erityisistä syistä katsotaan tarpeelliseksi.

\section{3 artikla}

Sopimuspuolten on pyrittävä helpottamaan Pohjoismaiden kansalaisten kansalaisoikeuden saamista muussa Pohjoismaassa.

\section{4 artikla}

Sopimuspuolten on jatkettava lakiyhteistyötä mahdollisimman suuren yhdenmukaisuuden saavuttamiseksi yksityisoikeuden alalla.

\section{5 artikla}

Sopimuspuolten olisi pyrittävä yhdenmukaistamaan rikosta ja rikoksen seuraamuksia koskevat säännöksensä.

Toisessa Pohjoismaassa tehdyn rikoksen tutkinnan ja syytteeseen panon tulisi mahdollisimman laajalti voida tapahtua myös toisessa Pohjoismaassa.

\section{6 artikla}

Sopimuspuolten on pyrittävä muunkin kuin edellä mainitun lainsäädännön keskinäiseen yhtenäistämiseen sellaisilla aloilla, joilla tämä näyttää tarkoituksenmukaiselta.

\section{7 artikla}

Jokaisen sopimuspuolen olisi toimittava sellaisten säännösten aikaansaamiseksi, että toisen Pohjoismaan tuomioistuimen tai muun viranomaisen päätös voidaan panna täytäntöön myös asianomaisen sopimuspuolen alveella.

\section{Sivistyksellinen yhteistyö}

\section{8 artikla (2)}

Pohjoismaissa on kouluissa annettavaan opetukseen ja koulutukseen sopivassa laajuudessa sisällytettävä muiden Pohjoismaiden, mukaan luettuna Färsaarten, Grönlannin ja Ahvenanmaan kielten, kulttuurin ja yleisten yhteiskuntaolojen opetusta.

\section{9 artikla}

Jokaisen sopimuspuolen olisi opetuslaitoksissaan ylläpidettävä ja laajennettava toisesta Pohjoismaasta kotoisin olevan opiskelijan mahdollisuuksia harjoittaa opintoja ja suorittaa tutkintoja niissä. Tällöin olisi myös jossakin Pohjoismaassa suoritettu osatutkinto mahdollisimman laajalti voitava lukea hyväksi loppututkintoa varten muussa Pohjoismaassa.

Kotimaasta käsin annettava taloudellinen apu olisi voitava suorittaa riippumatta siitä, missä maassa opintoja harjoitetaan.

\section{0 artikla}

Sopimuspuolten olisi yhtenäistettävä sellainen julkinen koulutus, joka tarkoittaa pätevyyden antamista määrätyn ammatin harjoittamiseen.

Sellaisen koulutuksen olisi mikäli mahdollista annettava sama pätevyys kaikissa Pohjoismaissa. Kuitenkin voidaan vaatia sellaisia lisäopintoja, jotka kansallisiin oloihin liittyvistä syistä saattavat olla tarpeellisia.

\section{1 artikla}

Aloilla, joilla yhteistyö on tarkoituksenmukaista, olisi opetuslaitosten kehittäminen yhtenäistettävä kehittämissuunnitelmia ja niiden toteutusta koskevan jatkuvan yhteistoiminnan puitteissa. 


\section{2 artikla}

Yhteistyö tutkimuksen alalla olisi suunnattava siten, että käytettävissä olevat tutkimusmäärärahat ja muut voimavarat yhtenäistetään ja käytetään hyväksi parhaalla mahdollisella tavalla, muun muassa perustamalla yhteisiä laitoksia.

\section{3 artikla}

Sivistyksellisen kehityksen tukemiseksi ja vahvistamiseksi on sopimuspuolten edistettävä vapaata pohjoismaista kansansivistystyötä ja vuorovaikutusta kirjallisuuden, taiteen, musiikin, teatterin, filmin ja muilla kulttuurin aloilla; tällöin tulee muun muassa ottaa varteen radion ja television tarjoamat mahdollisuudet.

\section{Sosiaalinen yhteistyö}

\section{4 artikla}

Sopimuspuolten on pyrittävä säilyttämään ja edelleen kehittämään yhteisiä pohjoismaisia työmarkkinoita aikaisempien sopimusten sisältämien suuntaviivojen mukaisesti. Työnvälitys ja ammatinvalinnanohjaus on yhtenäistettävä. Harjoittelijain vaihdon on oltava vapaata.

Kansalliset työväensuojelua ja muita senlaatuisia kysymyksiä koskevat säännökset olisi pyrittävä yhdenmukaistamaan.

\section{5 artikla}

Sopimuspuolten on toimittava siihen suuntaan, että jonkin Pohjoismaan kansalainen oleskellessaan muussa Pohjoismaassa mahdollisimman laajalti pääsee osalliseksi oleskelumaan omille kansalaisilleen tarjoamista sosiaalisista eduista.

\section{6 artikla}

Sopimuspuolten on edelleen kehitettävä yhteistyötä terveyden- ja sairaanhoidon, raittiushuollon sekä lasten ja nuorisonhuollon alalla.

\section{7 artikla}

Jokaisen sopimusmaan on pyrittävä lääkinnöllisen, teknillisen tai muun sentapaisen turvallisuustarkastuksen suorittamiseen siten, että tarkastuksesta annettu todistus voidaan hyväksyä muissa Pohjoismaissa.

\section{Taloudellinen yhteistyö}

\section{8 artikla}

Sopimuspuolten on edistääkseen Pohjoismaiden taloudellista yhteistyötä eri aloilla neuvoteltava talouspolitiikasta. Tällöin on kiinnitettävä huomiota mahdollisuuksiin sopeuttaa toisiinsa toimenpiteet, joihin ryhdytään suhdanteiden tasoittamiseksi.

\section{9 artikla}

Sopimuspuolten tarkoituksena on siinä laajuudessa kuin mahdollista edistää maidensa välistä yhteistyötä tuotannon ja sijoitustoiminnan alalla ja tällöin pyrkiä lvomaan edellytykset välittömälle yhteistyölle kahdessa tai useammassa Pohjoismaassa olevien yritysten kesken. Sopimuspuolten olisi kansainvälistä yhteistyötä edelleen kehitettäessä pyrittävä maiden välillä tarkoituksenmukaiseen työnjakoon tuotannon ja sijoitustoiminnan alalla.

\section{0 artikla}

Sopimuspuolten on toimittava mahdollisimman laajan pääomansiirtojen vapauden hyväksi Pohjoismaiden välillä. Muissa osapuolia yhteisesti kiinnostavissa maksu- ja valuuttakysymyksissä on pyrittävä yhteisiin ratkaisuihin.

\section{1 artikla}

Sopimuspuolten on pyrittävä lujittamaan aikaisemmin aloitettua yhteistyötä kaupan esteiden poistamiseksi Pohjoismaiden väliltä sekä mahdollisimman laajalti edelleen vahvistamaan ja kehittämään tätä yhteistyötä. 


\section{2 artikla}

Sopimuspuolten on kansainvälisissä kauppapoliittisissa kysymyksissä pyrittävä niin hyvin kukin erikseen kuin yhteisesti edistämään Pohjoismaiden etuja ja tässä tarkoituksessa neuvoteltava keskenään.

\section{3 artikla}

Sopimuspuolten on toimittava tulliteknillisten ja tullihallinnollisten määräyksien yhtenäistämiseksi sekä tullitoiminnan yksinkertaistamiseksi siten että maiden välistä liikennettä voidaan helpottaa.

\section{4 artikla}

Pohjoismaista rajakauppaa koskevat määräykset on laadittava siten, että rajaseutujen asukkaille aiheutetaan mahdollisimman vähän haittaa.

\section{5 artikla}

Milloin tarve vaatii ja edellytykset kahden tai useamman sopimuspuolen alveen toisiinsa rajoittuvien osien yhteiseen taloudelliseen kehittämiseen ovat olemassa, on näiden osapuolten pyrittävä yhdessä edistämään sellaista kehitystyötä.

\section{Yhteistyö liikenteen alalla}

\section{6 artikla}

Sopimuspuolten on pyrittävä lujittamaan liikenteen alalla aikaisemmin aloitettua yhteistyötä ja kehittämään sitä maiden välisten yhteyksien ja tavaranvaihdon helpottamiseksi sekä sellaisten ongelmien tarkoituksenmukaiseksi ratkaisemiseksi, joita tällä alalla saattaa esiintyä.

\section{7 artikla}

Kahden tai useamman sopimuspuolen alvetta koskettavien liikenneyhteyksien rakentamisen on tapahduttava osapuolten välisten yhteisten neuvottelujen pohjalla.

\section{8 artikla}

Sopimuspuolten on pyrittävä säilyttämään ja edelleen kehittämään sitä yhteistyötä, joka on johtanut niiden alveiden muodostumiseen yhdeksi passintarkastusalueeksi. Pohjoismaiden välisen rajan ylittävien matkustajien tarkastusta on muutenkin yksinkertaistettava ja yhtenäistettävä.

\section{9 artikla}

Sopimuspuolten on yhtenäistettävä toiminta liikenneturvallisuuden lisäämiseksi.

\section{Yhteistyö ympäristönsuojelun alalla (3)}

\section{0 artikla (3)}

Sopimuspuolet pyrkivät mahdollisimman suuressa määrin sisäisessä lainsäädännössään ja sitä sovellettaessa samaistamaan muiden sopimuspuolten ympäristönsuojeluedut oman maan etuihin.

\section{1 artikla (3)}

Sopimuspuolet pyrkivät yhdenmukaistamaan ympäristönsuojelusääntönsä saavuttaakseen mahdollisimman suuren yhtenäisyyden saasteiden päästöä, ympäristömyrkkyjen käyttöä ja muita ympäristöhäiriöitä koskevien säännösten ja ohjeiden osalta.

\section{2 artikla (3)}

Sopimuspuolet pyrkivät yhtenäisiin ratkaisuihin luonnonsuojelu ja ulkoilualueiden erottamista sekä rauhoittamista ja muita kasvien tai eläinten suojelutoimenpiteitä koskevissa kysymyksissä.

\section{Muu yhteistyö}

\section{3 artikla (8)}

Sopimuspuolten osallistuminen eurooppalaiseen ja muuhun kansainväliseen yhteistyöhön antaa hyvät mahdollisuudet yhteistyöhön Pohjoismaiden kansalaisten ja pohjoismaisten yritysten hyväksi. Hallituksilla on tässä 
yhteydessä erityinen vastuu yhteisten etujen ja arvojen valvomisesta.

\section{4 artikla}

Sopimusmaan ulkoasiainhallinnossa Pohjoismaiden ulkopuolella toimivan virkamiehen on, siinä määrin kuin se on sopusoinnussa hänen virkatehtäviensä kanssa ja jos asemamaan taholta ei ole estettä, annettava apua myös muun Pohjoismaan kansalaiselle, jos tällä maalla ei ole edustustoa kysymyksessä olevalla paikkakunnalla.

\section{5 artikla}

Sopimuspuolten olisi aina silloin kun mahdolliseksi ja tarkoituksenmukaiseksi havaitaan, yhtenäistettävä toimintansa, joka tarkoittaa avunantoa kehitysmaille ja yhteistyötä niiden kanssa.

\section{6 artikla}

Toimenpiteisiin Pohjoismaiden ja pohjoismaisen yhteistyön tunnetuksi tekemiseksi olisi ryhdyttävä läheisessä yhteistyössä sopimuspuolten ja niiden ulkomaista tiedotustoimintaa hoitavien elinten kesken. Milloin tarkoituksenmukaiseksi katsotaan voivat yhteiset esiintymiset tulla kysymykseen.

\section{7 artikla}

Sopimuspuolten on toimittava virallisen tilaston eri haarojen yhtenäistämiseksi

\section{Erillissopimukset (3)}

\section{8 artikla (3)}

Tarkemmat määräykset yhteistyöstä tässä sopimuksessa mainituilla aloilla voidaan antaa erillissopimuksin.

\section{Pohjoismaisen yhteistyön muodot}

\section{9 artikla (4)}

Pohjoismaisen yhteistyön toteuttamiseksi ja edelleen kehittämiseksi tämän ja muiden sopimusten mukaisesti tulee Pohjoismaiden jatkuvasti neuvotella keskenään ja tarvittaessa ryhtyä yhdenmukaisiin toimenpiteisiin.

\section{0 artikla $(4,8)$}

Pohjoismaiden välinen yhteistyö tapahtuu Pohjoismaiden neuvostossa, Pohjoismaiden ministerineuvostossa sekä pääministereiden, ulkoministereiden ja muiden ministereiden kokouksissa, erityisissä yhteistyöelimissä ja maiden ammattiviranomaisten välillä.

\section{1 artikla}

Kahden tai useamman sopimuspuolen yhteistyöhön perustuvaa säännöstä älköön osapuoli muuttako ellei siitä ole ilmoitettu muille osapuolille. Kiireellisissä tapauksissa tai kun kysymyksessä on säännös, jolla ei ole sanottavaa merkitystä, ei ilmoitusta kuitenkaan vaadita.

\section{2 artikla}

Pohjoismaiden viranomaiset voivat olla välittömässä kirjeenvaihdossa keskenään muissa asioissa kuin sellaisissa, jotka luonteensa puolesta taikka muusta syystä on käsiteltävä ulkoasiainhallinnon välityksellä.

\section{3 artikla (3)}

Pohjoismaiden yhteistyössä on pyrittävä mahdollisimman laajaan julkisuuteen.

\section{Pohjoismaiden neuvosto (5)}

\section{4 artikla $(5,2)$}

Pohjoismaiden neuvostossa Pohjoismaiden sekä Färsaarten, Grönlannin ja Ahvenanmaan kansanedustuslaitokset, maiden hallitukset sekä Färsaarten ja Grönlannin maakuntahallitukset ja Ahvenanmaan maakuntahallitus ovat yhteistyössä keskenään. Neuvosto voi tehdä aloitteita ja antaa neuvoja niissä kysymyksissä, jotka koskevat yhteistyötä näiden maiden tai joidenkin niistä ja Färsaarten, Grönlannin ja Ahvenanmaan välillä, ja sillä on 
muutoin ne tehtävät, jotka ilmenevät tästä tai muista sopimuksista.

\section{5 artikla (5)}

Neuvosto voi hyväksyä suosituksia, tehdä muita esityksiä tai antaa lausuntoja yhdelle tai useammalle Pohjoismaan hallitukselle tai ministerineuvostolle.

\section{6 artikla (5)}

Neuvostolle on, sen lisäksi mitä erikseen on sovittu, varattava tilaisuus antaa lausuntonsa merkittävistä pohjoismaista yhteistyötä koskevista kysymyksistä, milloin tämä ajan puutteen vuoksi ei ole mahdotonta.

\section{7 artikla $(5,2,8)$}

Neuvoston muodostavat 87 valittua jäsentä, hallitusten edustajat sekä Färsaarten ja Grönlannin maakuntahallitusten ja Ahvenanmaan maakunnanhallituksen edustajat.

Jäsenistä valitsevat Tanskan kansankäräjät kuusitoista, Suomen eduskunta kahdeksantoista, Islannin altingi seitsemän, Norjan suurkäräjät ja Ruotsin valtiopäivät kumpikin kaksikymmentä sekä Färsaarten ja Grönlannin maakäräjät ja Ahvenanmaan maakuntapäivät valitsevat jokainen kaksi jäsentä. Sen lisäksi kukin kansanedustuslaitos valitsee vastaavan määrän varajäseniä.

Jäsenet ja varajäsenet valitaan vuosittain, ja vaali on voimassa siksi kunnes seuraava vaali toimitetaan. Vaaleissa on erilaisten poliittisten suuntausten saatava edustus neuvostossa.

Ainoastaan se, joka on vaalin toimittaneen kansanedustuslaitoksen jäsen, voi toimia neuvoston valittuna jäsenenä ja varajäsenenä.

Hallitukset ja maakuntahallitukset määräävät jäsenistään halvamansa määrän edustajia.

\section{8 artikla $(5,2,8,9)$}

Tanskan valtakunnan valtuuskunnan muodostavat kansankäräjien valitsemat jäsenet ja hallituksen määräämät edustajat sekä Färsaarten ja Grönlannin toisessa kappaleessa mainitut valtuuskunnat. Suomen valtuuskunnan muodostavat eduskunnan valitsemat jäsenet ja hallituksen määräämät edustajat sekä toisessa kappaleessa mainittu Ahvenanmaan valtuuskunta. Kunkin muun maan valtuuskunnan muodostavat kansanedustuslaitoksen valitsemat jäsenet ja hallituksen määräämät edustajat.

Färsaarten valtuuskunnan muodostavat maakäräjien valitsemat jäsenet ja maakuntahallituksen määräämät edustajat. Grönlannin valtuuskunnan muodostavat maakäräjien valitsemat jäsenet ja maakuntahallituksen määräämät edustajat. Ahvenanmaan valtuuskunnan muodostavat maakuntapäivien valitsemat jäsenet ja maakuntahallituksen määräämät edustajat.

Valtuuskunta tarkoittaa 58 artiklan 2 kappaleessa maan valtuuskuntaa.

\section{9 artikla $(5,2)$}

Hallitusten sekä maakuntahallitusten ja maakunnanhallituksen edustajilla ei ole äänioikeutta neuvostossa.

Maiden välisten sopimusten soveltamista koskevissa kysymyksissä on ainoastaan näitä maita edustavilla jäsenillä äänioikeus.

\section{0 artikla (5)}

Neuvoston elimiä ovat yleiskokous, puheenjohtajisto ja valiokunnat.

\section{$\mathbf{5 1}$ artikla $(5,7,9)$}

Yleiskokouksen muodostavat kaikki neuvoston jäsenet.

Yleiskokous pitää vähintään kerran vuodessa varsinaisen istuntonsa. Ylimääräinen istunto tai aihekohtainen istunto pidetään, kun puheenjohtajisto niin päättää tai milloin vähintään kaksi hallitusta tai vähintään kaksikymmentäviisi valittua jäsentä sitä pyytävät. 
Yleiskokous käyttää neuvoston toimivaltaa, jollei muuta ole erikseen määrätty.

Asiain käsittely yleiskokouksessa on julkista, ellei yleiskokous toisin päätä.

\section{$\mathbf{5 2}$ artikla $(5,6,7,9)$}

Yleiskokous valitsee kalenterivuodeksi kerrallaan vuotuisessa varsinaisessa istunnossa puheenjohtajiston, johon kuuluvat presidentti ja Pohjoismaiden neuvoston työjärjestyksessä mainittu määrä muita jäseniä.

Eri poliittisten mielipidesuuntausten on oltava edustettuna puheenjohtajistossa. Kunkin maan tulee olla edustettuna puheenjohtajistossa.

Puheenjohtajiston jäsenen on oltava neuvoston valittu jäsen.

Puheenjohtajisto huolehtii neuvoston juoksevien asiain hoidosta ja edustaa muutoin neuvostoa siinä laajuudessa kuin tästä sopimuksesta ja neuvoston työjärjestyksestä ilmenee.

Neuvoston presidenttiys kiertää Pohjoismaiden kesken Pohjoismaiden neuvoston työjärjestyksestä ilmenevällä tavalla.

\section{$\mathbf{5 3}$ artikla $(5,9)$}

Yleiskokous määrää valiokuntien lukumäärän ja toimialat.

Valiokuntien tehtävänä on valmistella asioiden käsittelyä neuvostossa.

\section{$\mathbf{5 4}$ artikla $(5,6,7,9)$}

Neuvostoa avustaa sen toiminnassa puheenjohtajiston sihteeristö.

\section{$\mathbf{5 5}$ artikla $(5,2,7,9)$}

Oikeus tehdä ehdotuksia neuvostolle on hallituksilla, Färsaarten maakuntahallituksella, Grönlannin maakuntahallituksella, Ahvenanmaan maakuntahallituksella, ministerineuvostolla, neuvoston puheenjohtajistolla ja valiokunnilla sekä jäsenellä.

\section{6 artikla $(5,7)$}

Yleiskokous hyväksyy suosituksen tehdyn ehdotuksen pohjalta.

Puheenjohtajisto voi tehdä muunlaisen esityksen kuin suosituksen tehdyn ehdotuksen johdosta.

Yleiskokous antaa lausuntoja. Milloin puheenjohtajisto tekee esityksen, lausunnon antaa puheenjohtajisto.

Puheenjohtajiston on ilmoitettava yleiskokoukselle niistä toimenpiteistä, joihin se on toisen ja kolmannen kappaleen nojalla ryhtynyt.

\section{$\mathbf{5 7}$ artikla $(5,7)$}

Valittu jäsen voi tehdä kysymyksen hallitukselle tai ministerineuvostolle neuvostolle annetun kertomuksen tai ilmoituksen johdosta tai muutoin pohjoismaista yhteistyötä koskevassa asiassa.

\section{8 artikla $(5,2,7)$}

Jokainen valtuuskunta vastaa neuvoston toimintaan osallistumisestaan aiheutuvista kustannuksista.

Puheenjohtajisto päättää jokaisen varainhoitovuoden osalta siitä, miten yhteiset kustannukset jaetaan valtuuskuntien kesken.

\section{9 artikla (5)}

Yleiskokous vahvistaa neuvoston työjärjestyksen. Työjärjestyksen hyväksymiseen tai muuttamiseen vaaditaan kahden kolmasosan enemmistö neuvoston valituista jäsenistä.

\section{Pohjoismaiden ministerineuvosto (5)}

\section{0 artikla $(5,2)$}

Pohjoismaiden ministerineuvosto on Pohjoismaiden hallitusten yhteistyöelin.

Färsaarten ja Grönlannin maakuntahallitukset sekä Ahvenanmaan maakunnanhallitus ottavat osaa ministerineuvoston työhön. 
Ministerineuvosto tekee päätöksiä siinä laajuudessa kuin käy ilmi tästä sopimuksesta ja muista Pohjoismaiden välisistä sopimuksista. Muissakin yhteistyökysymyksissä ministerineuvosto vastaa Pohjoismaiden hallitusten sekä hallitusten ja Pohjoismaiden neuvoston välisestä yhteistyöstä.

\section{1 artikla $(5,1,2,8)$}

Hallituksen ja maakuntahallituksen jäseniä voi poikkeustapauksessa edustaa siihen valtuutettu henkilö. Kuitenkin on vähintään kolmea maata edustettava hallituksen jäsen.

Pääministereillä on vastuu pohjoismaisten yhteistyökysymysten yhteensovittamisesta. Heitä avustaa valittu hallituksen jäsen kustakin maasta (yhteistyöministeri) sekä valtiosihteeri tai virkamies (Pohjoismaiden yhteistyökomitean jäsen).

Puheenjohtajuus kiertää Pohjoismaiden hallitusten kesken erikseen sovittavalla tavalla. Puheenjohtajuuteen kuuluu vastuu Pohjoismaiden hallitusyhteistyön yhteensovittamisesta ja tarpeellisten aloitteiden tekemisestä. Puheenjohtajuuteen kuuluu ministerineuvoston ja muiden ministerikokousten sekä hallitusten eurooppalaisten ja muiden kansainvälisten kysymysten yhteisneuvottelujen työn johtaminen.

Ministerineuvostoa avustavat sen toiminnassa virkamieskomiteat ja ministerineuvoston sihteeristö.

\section{$\mathbf{6 2}$ artikla (5)}

Päätösvaltaisuus edellyttää, että kaikki maat ovat edustettuina ministerineuvostossa. Yksinomaan joitakin maita koskevien kysymysten käsittelyssä kuitenkin vain näiden maiden tulee olla edustettuina.

Jokaisella maalla on yksi ääni ministerineuvostossa.

Ministerineuvoston päätösten tulee olla yksimielisiä. Menettelytapakysymyksissä tehdään kuitenkin päätös äänestykseen osallistuvien yksinkertaisella äänten enemmistöllä ja äänten mennessä tasan puheenjohtajan ääni ratkaisee.

Äänestyksestä pidättyminen ei estä päätöksen tekemistä.

\section{3 artikla $(5,2,8)$}

Ministerineuvoston päätös on kutakin maata sitova. Päätös kysymyksessä, joka jonkin maan valtiosäännön mukaan edellyttää kansanedustuslaitoksen hyväksymistä, ei kuitenkaan ole tätä maata sitova ennen kuin kansanedustuslaitos on hyväksynyt päätöksen. Jos sanotunlainen hyväksyminen vaaditaan, on ministerineuvostolle ilmoitettava tästä ennen kuin ministerineuvosto tekee päätöksensä. Ennen kuin kansanedustuslaitoksen hyväksyminen on saatu, päätös ei ole myöskään toista maata sitova.

Tämän sopimuksen mukaisesti tehty päätös on Färsaaria, Grönlantia ja Ahvenanmaata sitova siltä osin kuin ne yhtyvät päätökseen itsehallintojärjestelmiensä mukaisesti.

\section{4 artikla $(5,6,8)$}

Ministerineuvoston tulee vuosittain antaa Pohjoismaiden neuvostolle kertomus pohjoismaisesta yhteistyöstä sekä selvitys tulevaa yhteistyötä koskevista suunnitelmista.

Puheenjohtajamaan pääministeri selostaa Pohjoismaiden neuvostolle yhteistyön päälinjat sekä hallitusten yhteistyön Eurooppaa koskevissa ja muissa kansainvälisissä kysymyksissä.

Ministerineuvoston tulee esittää menoarvioehdotuksensa Pohjoismaiden neuvostolle lausuntoa varten.

Pohjoismaiden neuvosto voi ehdottaa muutoksia painopistealueisiin ministerineuvoston esittämän budjettikehyksen puitteissa.

Ellei erityisiä syitä voida esittää, on ministerineuvoston noudatettava suositusta määrärahakäytöstä esitetyn budjettikehyksen puitteissa. 


\section{5 artikla (5)}

Ministerineuvoston tulee ennen jokaista Pohjoismaiden neuvoston yleiskokouksen varsinaista istuntoa antaa neuvostolle ilmoitukset niistä toimenpiteistä, joihin on ryhdytty neuvoston suositusten ja muiden esitysten johdosta. Jos suositus tai muu esitys on osoitettu yhdelle tai useammalle hallitukselle, voi ilmoituksen sen sijaan antaa se hallitus tai ne hallitukset, joille suositus tai esitys oli osoitettu.

\section{6 artikla (5)}

Ministerineuvosto vahvistaa työjärjestyksensä.

\section{7 artikla (5)}

Paitsi ministerineuvostossa voivat Pohjoismaiden hallitukset neuvotella keskenään myös pohjoismaisissa ministerikokouksissa.

\section{Yhteistyösopimuksen muuttaminen (5)}

\section{8 artikla (5)}

Ennen kuin maiden kesken sovitaan tämän yhteistyösopimuksen muuttamisesta, on Pohjoismaiden neuvostolle varattava tilaisuus antaa lausuntonsa.

\section{Loppumääräykset}

\section{Maaliskuun 23 päivänä 1962 allekirjoitetun} sopimuksen loppumääräykset

\section{9 artikla}

Tämä sopimus on ratifioitava ja ratifioimiskirjat mahdollisimman pian talletettava Suomen ulkoasiainministeriöön.

Sopimus tulee voimaan sen kuukauden ensimmäisenä päivänä, joka lähinnä seuraa päivää, jona kaikkien sopimuspuolten ratifioimiskirjat on talletettu.

\section{0 artikla}

Jos jokin sopimuspuoli haluaa irtisanoa sopimuksen, on siitä kirjallisesti ilmoitettava
Suomen hallitukselle, jonka viipymättä tulee antaa asiasta sekä ilmoituksen vastaanottamispäivästä tieto muille sopimuspuolille.

Irtisanominen koskee ainoastaan irtisanomisilmoituksen tehnyttä maata ja tulee voimaan sen kuukauden ensimmäisenä päivänä, joka alkaa kuuden kuukauden kuluttua siitä päivästä, jona Suomen hallitus vastaanotti irtisanomisilmoituksen.

Sopimus on talletettava Suomen ulkoasiainministeriöön ja oikeaksi todistetut jäljennökset siitä on Suomen ulkoasiainministeriön toimitettava kaikille sopimuspuolille.

Tämän vakuudeksi allekirjoittaneet, asianmukaisesti valtuutettuina, ovat allekirjoittaneet tämän sopimuksen.

Tehty Helsingissä yhtenä kappaleena islannin, norjan, ruotsin, suomen ja tanskan kielellä, jokaisen tekstin ollessa yhtä todistusvoimainen, kahdentenakymmenentenäkolmantena päivänä maaliskuuta yhdeksäntoistasataakuusikymmentäkaksi.

$[--]$

\section{3 päivänä helmikuuta 1971 allekirjoitetun} sopimuksen loppumääräykset

Tämä sopimus on ratifioitava ja ratifioimiskirjat mahdollisimman pian talletettava Suomen ulkoasiainministeriöön.

Sopimus on talletettava Suomen ulkoasiainministeriöön, jonka on toimitettava jokaiselle sopimuksen osapuolelle oikeaksi todistettu jäljennös sopimuksesta.

Sopimus tulee voimaan kolmantenakymmenentenä päivänä sen päivän jälkeen, jona kaikkien sopimuspuolten ratifioimiskirjat on talletettu.

Tämän vakuudeksi ovat allekirjoittaneet valtuutetut asiamiehet Kööpenhaminassa 13 päivänä helmikuuta 1971 allekirjoittaneet tämän sopimuksen, joka on tehty yhtenä islannin-, norjan-, ruotsin-, suomen- ja tanskankielisenä kappaleena jokaisen tekstin ollessa yhtä todistusvoimainen.

$[--]$ 
11 päivänä maaliskuuta 1974 allekirjoitetun sopimuksen loppumääräykset

Tämä sopimus on ratifioitava ja ratifioimiskirjat mahdollisimman pian talletettava Suomen ulkoasiainministeriöön.

Sopimus on talletettava Suomen ulkoasiainministeriöön, jonka on toimitettava jokaiselle sopimuksen osapuolelle oikeaksi todistettu jäljennös sopimuksesta.

Sopimus tulee voimaan kolmantenakymmenentenä päivänä sen jälkeen, jona kaikkien sopimuspuolten ratifioimiskirjat on talletettu.

Tämän vakuudeksi ovat allekirjoittaneet valtuutetut asiamiehet Kööpenhaminassa 11 päivänä maaliskuuta 1974 allekirjoittaneet tämän sopimuksen, joka on tehty yhtenä islannin-, norjan-, ruotsin-, suomen- ja tanskankielisenä kappaleena jokaisen tekstin ollessa yhtä todistusvoimainen. $[--]$

\section{5 päivänä kesäkuuta 1983 allekirjoitetun} sopimuksen loppumääräykset

Tämä sopimus on ratifioitava ja ratifioimiskirjat mahdollisimman pian talletettava Suomen ulkoasiainministeriöön, jonka on toimitettava jokaiselle sopimuksen osapuolelle oikeaksi todistettu jäljennös sopimuksesta.

Sopimus tulee voimaan kolmantenakymmenentenä päivänä sen päivän jälkeen, jona kaikkien sopimuspuolten ratifioimiskirjat on talletettu.

Tämän vakuudeksi ovat allekirjoittaneet valtuutetut asiamiehet Reykjavikissa 15 päivänä kesäkuuta 1983 allekirjoittaneet tämän sopimuksen, joka on tehty yhtenä islannin-, norjan-, ruotsin-, suomen- ja tanskankielisenä kappaleena jokaisen tekstin ollessa yhtä todistusvoimainen.

[- ]
6 päivänä toukokuuta 1985 allekirjoitetun sopimuksen loppumääräykset

Sopimus tulee voimaan kolmantenakymmenentenä päivänä siitä päivästä, jona kaikki sopimuspuolet ovat ilmoittaneet sopimuksen voimaansaattamiseksi vaadittavien toimenpiteiden suorittamisesta.

Suomen ulkoasiainministeriö ilmoittaa muille sopimuspuolille näiden hyväksymisilmoitusten vastaanottamispäivästä.

Sopimuksen alkuperäiskappale talletetaan Suomen ulkoasiainministeriön huostaan, joka toimittaa siitä oikeaksi todistetun jäljennöksen jokaiselle sopimuspuolelle.

Tämän vakuudeksi ovat asianmukaisesti valtuutetut allekirjoittaneet tämän sopimuksen.

Tehty Lundissa 6 päivänä toukokuuta 1985 yhtenä islannin-, norjan-, ruotsin-, suomen- ja tanskankielisenä kappaleena, jonka kaikki tekstit ovat yhtä todistusvoimaiset.

$[--]$

\section{1 päivänä elokuuta 1991 allekirjoitetun} sopimuksen loppumääräykset

Sopimus tulee voimaan kolmenkymmenen päivän kuluttua siitä, kun kaikki osapuolet ovat ilmoittaneet Suomen ulkoasiainministeriölle sopimuksen hyväksymisestä.

Suomen ulkoasiainministeriö ilmoittaa muille osapuolille näiden ilmoitusten vastaanottamisesta ja sopimuksen voimaantuloajankohdasta.

Tämän sopimuksen alkuperäiskappale talletetaan Suomen ulkoasiainministeriön huostaan, joka toimittaa siitä muille osapuolille oikeaksi todistetun jäljennöksen.

Tämän vakuudeksi ovat asianmukaisesti valtuutetut edustajat allekirjoittaneet tämän sopimuksen.

Tehty Tampereella 21 päivänä elokuuta 1991 yhtenä tanskan-, suomen-, islannin-, norjan- ja ruotsinkielisenä kappaleena, jonka kaikki tekstit ovat yhtä todistusvoimaiset. [- - ] 
18 päivänä maaliskuuta 1993 allekirjoitetun sopimuksen loppumääräykset

Sopimus tulee voimaan kolmenkymmenen päivän kuluttua siitä, kun kaikki osapuolet ovat ilmoittaneet Suomen ulkoasiainministeriölle sopimuksen hyväksymisestä.

Suomen ulkoasiainministeriö ilmoittaa muille osapuolille näiden ilmoitusten vastaanottamisesta ja sopimuksen voimaantuloajankohdasta.

Tämän sopimuksen alkuperäiskappale talletetaan Suomen ulkoasiainministeriön huostaan, joka toimittaa siitä muille osapuolille oikeaksi todistetun jäljennöksen.

Tämän vakuudeksi ovat asianmukaisesti valtuutetut edustajat allekirjoittaneet tämän sopimuksen.

Tehty Helsingissä 18 päivänä maaliskuuta 1993 yhtenä tanskan-, suomen-, islannin-, norjan- ja ruotsinkielisenä kappaleena, jonka kaikki tekstit ovat yhtä todistusvoimaiset. $[--]$

29 päivänä syyskuuta 1995 allekirjoitetun sopimuksen loppumäcäräykset Sopimus tulee voimaan viidentoista päivän kuluttua siitä, kun kaikki osapuolet ovat ilmoittaneet Suomen ulkoasiainministeriölle sopimuksen hyväksymisestä.

Suomen ulkoasiainministeriö ilmoittaa muille osapuolille näiden ilmoitusten vastaanottamisesta ja sopimuksen voimaantuloajankohdasta.

Tämän sopimuksen alkuperäiskappale talletetaan Suomen ulkoasiainministeriön huostaan, joka toimittaa siitä muille osapuolille oikeaksi todistetun jäljennöksen.

Tämän vakuudeksi ovat asianmukaisesti valtuutetut edustajat allekirjoittaneet tämän sopimuksen.

Tehty Kööpenhaminassa 29 päivänä syyskuuta 1995 yhtenä tanskan-, suomen-, islannin-, norjan- ja ruotsinkielisenä kappaleena, jonka kaikki tekstit ovat yhtä todistusvoimaiset.

$[--]$

\section{Viiteluettelo}

1 Uusi sanamuoto 1974.

2 Uusi sanamuoto 1983.

3 Uusi artikla vuodesta 1974.

4 Uusi sanamuoto 1971.

5 Uusi artikla vuodesta 1971.

6 Uusi sanamuoto 1985.

7 Uusi sanamuoto 1991.

8 Uusi sanamuoto 1993.

9 Uusi sanamuoto 1995. 
$\mathbb{B}$

Pohjoismaiden ministerineuvosto

Nordens Hus

Ved Stranden 18

1061 København K

www.norden.org 